\author{
M. Kalinina
}

\author{
Huzhou University, Huzhou City, Zhejiang Province, China
}

\title{
OVERVIEW OF ARCHITECTURE AND INTERIOR DESIGN IN CHINA AND EUROPE
}

\begin{abstract}
Chinese and European cultures have developed independently for hundreds of years. From the most simple everyday things, to language, lifestyle and thinking, absolutely everything is different. Our views on life, mentality, perceptions of death, even methods of raising children and faith are different. Each of these cultures is unique and unrepeatable. All these differences in our mentality are reflected not only in the way of life and thinking of people, but also in creativity. After all, creativity is a reflection of our existence. Music, art, architecture, design, all these creative directions bear the imprint of our life, the trace of our desires and requirements. I will draw parallels between cultures as different and wonderful as Chinese and European, I will trace the development of design and architecture, the influence of these two cultures on each other.
\end{abstract}

Keywords: Chinese, European, different, art, traditions, modern, building, style, develop.

\section{A look at ancient Chinese architecture}

I'll start with China. All countries have their own characteristics, their own original style in architecture and traditions, their ancient architectural structures, for different spheres of application. Residents of these countries consider these buildings a symbol of development and pride in their culture, and for foreigners these buildings have become a symbol of these countries. Such a symbol in China is the medieval Gate of Heavenly Peace or the Tiananmen Gate on the square in Beijing. This symbol has become so recognizable due to the fact that its image fell on the national emblem of the country, is a symbol of the ancient traditions of China and the great Chinese people. In the development of China, historians traditionally distinguish several periods with characteristic features, only inherent in architectural traditions and styles. Such as the earliest Shang Yin period and the Zhou period. All distributions are directly related to the peculiarities of the history and culture of all Chinese dynasties, kingdoms and provinces. For modern times, the continuity of tradition is characteristic, and especially as much as possible to preserve ancient architecture, culture, historical buildings with traditional importance, in different parts of the country. This is partly due to the ideas of Confucianism in China. Most of these magnificent structures of Chinese architecture have long been recognized as UNESCO World Heritage Sites.

The most striking example of the fact that modern society is trying to preserve ancient traditions, culture and especially architecture is the aforementioned Tiananmen Gate, which is preserved and reconstructed with trepidation and care. Despite all the concern for antiquities, it must be admitted that sometimes people are driven by their own benefit, and then all the care for the population is done only for the sake of money, as is the case with the traditional Syheyuanimi. They are rented to visitors, including foreigners, are converted into small catering points, in which national Chinese cuisine is prepared for tourists. It would be wrong to condemn such an attitude towards ancient architecture, but it can lead to the destruction of such beautiful and no doubt important historical architectural structures.

People always remain people, wars and confrontations will always be a part of our life, which leave a huge imprint not only in architecture, but also in other areas of creativity. Conflicts always force people to pay more attention to the construction of defense, fortifications and engineering structures. And in times of relative calm, people build palaces and entire palace cities such as the Forbidden City. Honestly, as a child, when I heard about this building, I imagined a city that you can't visit if you are a simple person. It seemed to me that this city is shrouded in magic and millions of secrets.

The name itself whispers that this city is full of amazing secrets, mysteries and adventure. When I grew up I realized that this place is really full of magic, but it is called architecture. This palace is recognized as one of the most significant palaces in the world. The majestic halls and passages are a prime example of character and embody the essence of Chinese architectural tradition. The erected palace complex corresponds to the importance of the imperial residence, located in the capital of the largest state in the world. Because of the belief in ancient China that the emperor was the son of heaven, the emperor's residence was built towards the north as an earthly image of the heavenly Purple Palace. To be a worthy home for the heavenly emperor, one can thus understand that the palace has a colossal size of $720,000 \mathrm{~m} 2$, of which 150,000 are occupied by buildings, 
and the buildings themselves consist of 90 palaces and courtyards, 980 buildings and 8,724 rooms. The palace complex itself consists of three parts of defensive structures, an outer courtyard and an inner courtyard. I will not describe in detail this majestic architectural structure, because it is already clear how large and impressive it is.

\section{Modern houses of China}

All the masterpieces of Chinese architecture that have survived to this day were destined to become the face of Chinese greatness. Hundreds of such buildings are scattered throughout China, a trace of an ancient and powerful civilization, which even now amaze with their grandeur and thoughtfulness in terms of design and architecture. Modern buildings on the territory of China amaze no less than ancient buildings. To begin with, consider not the world-famous buildings that have become the hallmark of China, but the simplest houses where the entire population of China lives. While doing an internship in a Chinese design company, I visited many objects, where I realized that even an ordinary resident can afford, not just his own house, but a small palace, where he will celebrate himself beautifully. Of course, there are flaws everywhere, and when they are talked about, they can be corrected.

A small problem with such houses is that, you need to accommodate the great population of this country, because of this, the houses themselves are sometimes not very wide, representing a narrow structure, and the ceilings are too low due to the built-in air-cooling systems. But by the external structure and facade, you can never say that these houses have a very narrow initial layout. Outwardly, they always look very majestic and luxurious. There are colossal advantages, the inhabitants of this country simply adore a lot of light in their home, therefore, although the original plan of the house does not take into account much more windows, they can always be redone, into simply colossal balconies. Sometimes such a solution, although it gives a bright space, also destroys the original thoughtful architectural structure, which was conceived by those who built these houses. Strange as it may seem, but such a decision as to remove all the walls, remembering them in places, or to add an elevator in three, or even a two-story house, does not in any way violate the stability and stability of such houses. The interior design of such houses at the moment is more inclined towards European styles, they are similar to the country villas of Spain and Greece, but at the same time the designers skillfully combine and mix the Chinese style with different European styles.

\section{The architecture of the megalopolises of China}

Now let's talk about the majestic architectural buildings of our time in China. No one will argue with the fact that in recent years China has become a clear leader in modern construction.

The tallest skyscrapers and unusual architectural buildings have appeared here. I would like to start with an amazing masterpiece, the Peking Opera. The 200,000 $\mathrm{m} 2$ theater is located in the immediate vicinity of Tiananmen Square and the House of Peoples. The unique building is an ellipsoidal dome made of glass and titanium, giving this building an incredible visual lightness, towering among a man-made reservoir, across the street from Zhongnanhai Lake. The three main halls can accommodate at least 6,500 spectators. The interior is striking in its beauty thanks to the colossal size of the windows and glass ceilings, the room is filled with light and air. The decor is also on your level, full-length statues of the musicians add a charming atmosphere. And lighting in warm colors sets you up for a pleasant evening that awaits visitors to this delightful place. A perfect sphere of titanium and glass is reflected in the water, forming an unfinished silhouette of the sphere. A delightful sight in the rays of the rising sun of China.

Another of the most striking landmarks striking with grandeur and grace is the Shanghai Tower. Which is a symbol of the new century and the technical might of China, the prosperity and prosperity of the nation. The building rises $632 \mathrm{~m}$ into the skies, ranking first in China and third in the world. The location of this giant is an equally famous area - the center of finance and trade in Pudong. This skyscraper has become the final element of the triad of the tallest buildings in the city. The unique building was made in the style of postmodernism, with its swiftness, harmony, and scale, this architectural creation is breathtaking, with its beauty and laconicism.

These are some of the most outstanding architectural structures not only in China but in the world. This civilization is the most ancient, it existed even before our era, and the architectural development exceeded its time. That is why we have the opportunity to observe such majestic buildings of ancient buildings. Each dynasty in China brought not only new perspectives on government, but also a distinct perspective on design and architecture.

\section{A look at the development of European architecture}

As for European architecture and design, it is difficult to trace one particular style or direction, because this is not one country within which one can talk about development or even periods of decline, there is not a lot of countries with their own unique architecture and special design. For hundreds of years from the beginning, they remained unique, and then gradually borrowed some features from their neighbors and successfully combined them with each other, thereby developing their various directions.

I'll try to find similarities in design and architecture, 
and I'll start from the middle of the 1st millennium, from about the 5th-7th century. The emergence of a new style, which has a significant impact on the formation of the ideas of the entire world art of that time, is the Romanesque style. This style is suitable primarily for the buildings of temples and monasteries. Religion for Europe at that time has always had a very large weight in society. Most of the buildings built during this period were fortresses.

There was no stylistic unity in Italian architecture and design. This is largely due to the fragmentation of Italy and the gravitation of its individual regions to the culture of Byzantium or the Romanesque - those countries with which they were connected by long-term economic and cultural communication. Local late antique and early Christian traditions, the impact of the art of the medieval West and East determined the originality of the Romanesque architecture of the advanced schools of Central Italy - the cities of Tuscany and Lombardy. freed from feudal dependence and began the extensive construction of city cathedrals. Lombard architecture was instrumental in the development of the vaulted structure and skeleton of the building. In the architecture of Tuscany, the ancient tradition manifested itself in the completeness and harmonious clarity of forms, in the festivity of the appearance of the majestic ensemble in Pisa. It includes a five-aisled Pisa Cathedral (10631118), a baptistery (baptismal, 1153 - 14th century), an inclined bell tower - Campanile (Leaning Tower of Pisa, begun in 1174, completed in the 13-14th centuries) and the Camio cemetery - Santo. Each building stands out freely, standing out for its simple enclosed volumes of a cube and a cylinder and the sparkling white of marble in a green grass-covered square near the Tyrrhenian Sea. In the breakdown of the masses, proportionality has been achieved. Graceful white marble Romanesque arcades with Roman-Corinthian and composite capitals divide the facade and outer walls of all structures into tiers, facilitating their massiveness and emphasizing the structure. The large cathedral gives an impression of lightness, which is enhanced by inlays of colored marble of dark red and dark green (a similar decor was typical for Florence, where the so-called "inlay style" became widespread). An elliptical dome above the crosshair completed its clear and harmonious image.

In Germany, he became such representatives. St. Peter's Cathedral in Worms. As mentioned above, faith was very important, at that time Catholicism was the main religion in Germany. This was reflected in the interior of the cathedral. As with all, the main shrine of the church is the altar, which was created by the famous master working in this style, Baltazar Neiman. The temple amazes not only with its skillfully executed stucco molding, scale, but also the organ, which was installed in the 20th century. The interior decoration is amazing, it has its own unusual and unrepeatable style. The statues of saints and stucco moldings, made in the Baroque style, are superbly combined with the massive columns that support the vaults of the cathedral. The vaults themselves resemble the naves of the temple, visually repeating them. The statues and decorative elements are gilded, and when the rays of the sun penetrate into the interior of the cathedral, not getting gilded, they illuminate the church with their radiance. the hall is a low, poorly lit temple, with a simple plan, with a little protruding transept, with a poorly developed choir, framed by only three chapels. Almost equal in height, the three naves are covered with semi-cylindrical vaults and a common gable roof. The lower tier of the western facade is dissected by a portal and two semicircular arches extending into the thickness of the steppe. The upward movement, expressed by small pointed towers and a stepped pediment, is stopped by horizontal friezes with sculptures of saints. Rich ornamental carvings, typical of the Poitou school, spread over the surface of the wall, softening the severity of the structure. In the grandiose temples of Burgundy, which took first place among other French schools, the first steps were taken to change the design of vaulted ceilings in the type of a basilical temple with a high and wide middle nave, with many altars, transverse and side ships, an extensive choir and a developed, radially located crown chapels. The high, three-tiered central nave was covered with a box vault, not with a semicircular arch, as in most Romanesque churches, but with light lancet outlines.

The temples of Burgundy are close to her: in Parais le Manial (early 12th century), Wesede (first third of the 12 th century) and Autun (first third of the 12th century). They are characterized by the presence of a wide hall located in front of the naves, the use of high towers. Burgundian temples are distinguished by perfection of forms, clarity of dismembered volumes, regularity of rhythm, completeness of parts, their subordination to the whole.

Monastic Romanesque churches are usually small in size, vaults are low, transepts are small. With a similar layout, the design of the facades was different. For the southern regions of France, near the Mediterranean Sea, for the temples of Provence (in the past, the ancient Greek colony and the Roman province), a connection with the ancient posture of non-Roman order architecture is characteristic, the monuments of which have been preserved here in abundance, hall temples, simple in forms and proportions, dominated, distinguished by the richness of sculptural decor on facades that sometimes resembled Roman triumphal arches (the Church of SaintTrofim in Arles, 12th century). Modified domed structures penetrated the southwestern regions.

Most of the monuments of Romanesque art are in France. In the architecture of Central and Western France, there is the greatest diversity in solving constructive problems. Strikingly pronounced features of the 
Romanesque style, exterior and interior, are the Church of Notre Dame la Grande in Poitiers (11-12 centuries). This building is a low, poorly lit temple with a simple plan, the whole point is in the heretical teachings that were prevalent at that time in France.

These are just a couple of examples in one specific style, and there are hundreds of such trends in the development of art. You can endlessly list all the buildings in the Romanesque or Gothic style that followed it. Epochs, styles, trends in design covered all of Europe gradually, they replaced each other, in some country it happened faster, in some a little later, but sooner or later everything changed. Styles changed, the directions in which countries developed, the borders of states changed, peace gave way to war, and then peace came again. All this leaves its mark on history, art, design and architecture.

A great impetus for the further development of all architecture in Europe was the architecture of the Renaissance, which raised the social status and the role of the master designing buildings. The basic principles of this style were formulated at the beginning of the 15th century and were fundamental for two more centuries. The proportions of the building, its symmetry about one or more axes, the strict order of the columns, pilasters, niches were of great importance in the design. The emergence and development in urban planning of such well-known styles as baroque, rococo and classicism had a huge impact on the formation of the appearance of the European house. As for the interior of simple houses of residents, they were not similar to each other depending on climatic conditions, not only the style of architecture and design of the premises was changing, but also the materials from which all buildings were built, thereby changing construction methods and style for themselves. The roof in Scandinavian-type houses can be flat, but it is rarely installed on buildings due to the difficulty of removing snow and its melting in the spring. As roofing materials, metal tiles, roofing copper, bitumen shingles and other modern coatings are used that can qualitatively protect buildings from moisture and dampness. Window openings and frames are large, panoramic glazing can be used. Bay windows and balconies are absent in Scandinavian buildings, and carved wooden elements serve as decoration of the facades. The porch often has a wooden staircase with carved balusters.

\section{Modern development of architecture in Europe}

As far as modern architecture is concerned, European homes are especially suitable for private plots in rural areas. But they are also popular in small towns where high-rise apartment buildings are not usually built. The similarity of all modern technologies used in the construction of buildings is based on the structure of the frame. There are different methods of installation, fastening of individual units and elements, materials used for insulation. The differences are due to the possibility of using those resources and materials, the production of which has been launched at factories located nearby.

Unlike Canadian-assembled frame houses, which take up to four months to build, houses in Germany are built very quickly, literally in a few days ... Automatic lines are installed at the factories, the assembly of frames takes place in warm and dry workshops, which significantly increases the quality and duration of the further operation of buildings. Such automatic lines are currently operating in most industrial, developed countries, not only in Europe, but also in other parts of the world. Building a European home is beneficial for several reasons. Very short construction time. Possibility of easy replacement of both individual elements and parts of the supporting frame. Low cost of buildings with excellent quality. The frame is made of special glued beams, not subject to deformation and impregnated with antiseptics and antifungal mixtures. Ecological cleanliness.

As for modern architecture and design, here, as in Chinese, everything is not unambiguous and each person has his own tastes and views on the design of his own home. And it's hard to pick out a specific line of style for all the buildings. Now, in our turbulent time, it is customary to mix styles with each other and thereby create new directions in stylistic solutions. So many new directions have appeared thanks to unusual solutions and cooperation of designers and architects from different countries. The prerequisite for the revolution in architecture was a breakthrough in building technologies, or rather, the appearance of reinforced concrete. Thanks to him, the architects moved away from massive brick walls and simplified the structural scheme to a frame one. The columns replaced the load-bearing walls and allowed the introduction of striped glazing, thus illuminating a large area of the space. Pitched roofs have also undergone metamorphosis, giving way to flat roofs that increase the usable area.

Without going into engineering, you can see that all the changes did not happen just like that. Each detail has its own rationale, as does its absence. The purpose and function of the components dictate the global transformation of the external appearance of the building. And beauty, in turn, lies in honesty: if there is concrete, then it is not covered, the ramp becomes an accent in the interior, the windows completely change the appearance of the building. Each element is self-sufficient and open to the observer.

The main trends that are guiding designers today are environmental friendliness, personalization, functionality.

\section{Sustainability}

Conserving the planet's resources is one of the global challenges that is reflected in interior design as 
well. In order for a thing to be considered environmentally safe, it is necessary that it does not harm nature either during production or during operation.

From this point of view, natural materials are considered the best, which serve for a long time, and then they can be easily disposed of. These are wood, glass, metal, natural stone - the use of such materials is quite expensive, but the result is worth it. You get a visually flawless environment that is safe for the planet.

A popular eco-design trick is the use of plants in interiors. Not everyone loves flowers and greenery in pots, but now there is a very interesting alternative - green walls and panels. It is not only beautiful and stylish, but also useful - green walls create an optimally comfortable, healthy microclimate in the house.

\section{Personalization}

Fashionable interiors are becoming more personalized, reflecting the tastes of the owners. There is no need to hesitate to show your individuality - any preferences can be reflected in the setting very beautifully and delicately. If desired, they can be made the center of the composition, or they can be carefully included in the project as nuances. In any case, such things help to create a unique character of the living space, to emphasize its atmosphere. Personalization of interiors is a rather expensive pleasure, since designers are faced with the task of finding not only the desired image, but also real objects that will broadcast it. Anything can act as style-forming elements - a bright wall, a vintage piece of furniture, a fireplace, interesting zoning. It is important not to be afraid of new ideas and trends in apartment design offered by designers - even if you have not seen anything like it anywhere, but the proposed solution reflects your thoughts, it is worth considering it. At the same time, there is no need to try to create originality for the sake of originality - it always looks very tortured and unnatural. A professional designer will help to embody the most non-standard idea in such a way that it will be not only beautiful, but also convenient.

\section{Functionality}

This is the simplest and most practical principle only those things that will be useful to you are included in the interior. This applies to all styles, in each of them you can work out all the elements from the point of view of practicality. For example, you like wicker baskets or ceramic boxes - these things may just be dust collectors, but with the right approach, they turn into practical and convenient storage systems. Each item in a functional interior should have its own purpose. It is not entirely rational to occupy space with things just so that there is no emptiness. Actually, emptiness, free space is very good, and there is no need to spoil such an advantage by cluttering the place with objects of dubious value. If you have collections or things that have no practical purpose, but you want to show them, you can create a separate zone for this, which will become one of the interior features. And this will make sense - the displayed collection will become a reflection of the achievements or tastes of the owners, which perfectly corresponds to the principle of personalization.

\section{Culture Exchange}

From history, I remember that many inventions came from China to Europe, from gunpowder and paper to a folding umbrella. However, at the dawn of 20th century European design history, many of the key items were in turn directly influenced by Eastern culture. A classic example is the armchairs of the famous Danish designer Hans Wegner. In 1943, while walking through one of the museums in Copenhagen, he saw a Chinese chair of the Ming era - and created seven versions based on it, which brought fame not only to him, but to the entire Danish design: The Round Chair has become a real icon. In February 1950, the American magazine Interiors declared it the most beautiful chair in the world. But the first European designer to draw attention to the Far Eastern culture was Eileen Gray. While still a student, she became interested in the technique of varnishing wood, and after moving to Paris at the beginning of the twentieth century, she met the Japanese master Seizo Sugawara and took lessons from him. Among Eileen Gray's works are wall panels, lacquered armchairs (one of them, with armrests in the shape of curved dragons, was sold in 2009 at Christie's for a record \$ 28 million), screens, dressing tables and bureaus, made by hand. Contemporary European designers travel to the East to comprehend traditional crafts, to study the intricacies of Eastern philosophy and minimalist aesthetics. But not only. The young and fast-growing design industry in China provides great opportunities for self-realization: it is much easier to launch a new product here than in Europe, where both competition and cost are off scale.

As for the influence of European architecture on Chinese architecture, everything is not as easy as it seems. At the moment, I noticed that the very architecture of simple residential buildings in China very much copies the style of houses in Italy, Spain, Greece. But always with its own changes, taking into account the wishes and needs of local residents. The very influence of these different cultures on each other is undeniable, somewhere more well, somewhere less, one cannot but agree that this brings new opportunities for the architectural structure, for design solutions. Looking at the influence of China, then we will not talk about the influence of Chinese culture, but about some stylistic decisions that bring the Chinese style to European homes.

\section{Result}

We can go to the conclusion that modern architecture and design, in different countries, until the moment when people actively began to share information, there are many differences, but with the 
advent of development, we began to share information, knowledge, skills. Thanks to this, more and more varieties of styles began to appear in our homes, cities and countries; over time, people did not just copy new directions in design, but created a completely new one thanks to a mix of styles. This is influenced by many factors, from climatic conditions to lifestyle and thinking. In our century, it has become popular to borrow from others and this has led to the fact that now we can observe the architecture of knowledge or design that is completely inherent in the region in which it is located. So modern designers do not just copy the styles of whole people, but thanks to this, they open more and more new directions and art.

\section{References}

1. Wang, Min. (2019). On Chinese Traditional Simplicity Thought Taking Ming-style Furniture as an Example. Art, (29), 15-16. URL: https:/kns.cnki.net/kcms/detail/detail.aspx?dbcode=CJFD\&dbname $=$ CJFDLASN2019\&filename=YSPJ201929013\&uniplatform=NZKP T\&v= a3VEulBqlDI5qMWu3RLuxXlo 7F1iVfy7O8R wZjBeJDREH16J80iwoE4-14iZ [in Chinese]

2. Yang, Xianyi, Yongdong, Wang. (2018). The wind of simple design in the context of China's conservation-oriented society. Packaging, 39(20), 126-132. URL: https://kns.cnki.net/kcms/detail/detail.aspx?dbcode=CJFD\&dbname $=$ CJFDLAST2018\&filename $=$ BZGC201820023\&uniplatform $=$ NZ KPT\&v=ipNEBG0CSpCoiYr--qBdq2tiiX28jxZOlLzyK9LccVJuipMbb5upt8jy4FqQ651 [in Chinese]

3. Liang, Long. (2016). Optimistic about the simple design of Chinese market and leading the new trend. China Textile, (05), 86-87. URL: https://kns.cnki.net/kcms/detail/detail.aspx?dbcode=CJFD\&dbname $=$ CJFDLAST2016\&filename $=$ FAZI201605028\&uniplatform $=$ NZKP T\&v=2kYIZhz23jt8L4cP9KmcifTjsSGpTJHH0kdkcQKwT0WmvP TUxMa37S38BABwPoCL [in Chinese]

4. Cao, Xiaoyun. (2015). Analysis on the Application of Simple Design Concept in Lamps and lanterns. Enterprise Technology and Development, 12, 28-29. URL: https://kns.cnki.net/kcms/detail/detail.aspx?dbcode=CJFD\&db name $=$ CJFDLAST2015\&filename $=$ ZXQK201512013\&unipla tform=NZKPT\&v=TGIcxlqzcDDPL4e9_u-

Yfo Ym04RG31jccKdj-1Zh-LTsEz-LoMaqBbTIVXfN3L [in Chinese]

5. Fan, Yu. (2016). The Influence of Chinese Traditional Facebook Art on Modern Simple Design. Technology, 29(06), 261. URL: https://kns.cnki.net/kcms/detail/detail.aspx?dbcode $=$ CJFD\&db name $=$ CJFDLAST2016\&filename $=$ YSKK201606225\&uniplat form=NZKPT\&v=Szx1JrhYH91_s_HBlwx6ci1tNRzpUiDRwc crcZ1WM1Vay9-78jUyg6iwXydyxye8 [in Chinese]

6. Wang, Min. (2015). Research on Product Design Based on "Minimalism". Engineering Technology II Series, TB 472, 66. URL: https://kns.cnki.net/kcms/detail/detail.aspx?dbcode=CMFD\&dbname $=$ CMFD201801\&filename $=1015810393$.nh\&uniplatform=NZKPT \&v=2FpamJkKM0M86rvd ZD2nIdLEeTH85Y9UEx8tQZ5REPBn nhCnWcJH5zTN-23dhnP [in Chinese]

7. Chen, Guangyuan, Cheng, Xueyuan, Zhang, Yalu, Liu, Xianzhong. (2019). Research on the Application of Minimalism Style in Interior Design. Furniture and interior decoration, (02), 114-115. URL: https:/kns.cnki.net/kcms/detail/detail.aspx?dbcode=CJFD\&dbname= CJFDLAST2019\&filename $=$ JJZS201902036\&uniplatform $=$ NZKPT $\& \mathrm{v}=$ AqPcaJMUOu9qnNucybU0AePNhDryG8YqypALT1x1WDKf -roSgJA-5r6fCHbStRd- [in Chinese]
8. Gao, Sheng. (2016). Application of Chinese Traditional Elements in Modern Interior, Modern Decoration (Theory), (07), TU238.2, $56 . \quad$ URL: https://kns.cnki.net/kcms/detail/detail.aspx?dbcode=CJFD\&db name $=$ CJFDLAST2016\&filename $=$ XDZS201607088\&uniplat form=NZKPT\&v=Ae2Nff7DZYtqqB9uqSP8ToEF18a_BV8P 5eXYTaMLUVJMiGKoWlhG5RgMBhX48sgE [in Chinese] 9. Ren, Meiqi, Guo, Weiqiang. (2014). Thinking and discussion on cultural construction in the field of interior design. Technology, 27(02), $327 . \quad$ URL: https://kns.cnki.net/kcms/detail/detail.aspx?dbcode $=$ CJFD\&db name $=$ CJFD2014\&filename $=$ YSKK201402286\&uniplatform $=$ NZKPT\&v=eDoPuVdJ-hy3KXL2WnS5YcZ60Q0I-

Oy7UDVaS4dquoFcK4aVJIteHbWPNss_B8IJ [in Chinese]

10. Zhang, Yi. (2013). On the application of minimalism in interior design. China, (33), TU238.2;J525.1, 250. URL: https://kns.cnki.net/kcms/detail/detail.aspx?dbcode=CJFD\&dbname= CJFDLASN2014\&filename=SHZH201333229\&uniplatform=NZK PT\&v=wctyt02HVsaSuTIKEnepnG-

QD0jxIRV5s20uLbjW0rYvUEF7JM0kxMjBP-yepKaX [in Chinese] 11. Zhang, Fucheng, Wang, Dan. (2018). On the Application of Minimalism Style in Interior Fumiture Design. Industry, (02), 78-79. URL: https:/kns.cnki.net/kcms/detail/detail.aspx?dbcode=CJFD\&dbname=CJF DLAST2018\&filename-GYSH201802034\&uniplatform=NZKPT\&v= 4KERGcbVjyZDPw7fynPanqV13fAWOpeXGpQZHe5fH428iCEHSE J111Ty1YeNZ8Nv [in Chinese]

12. Xiong, Weixiang. (2021). Integration of Chinese Traditional Culture and Modern Interior Design. Culture, (32), 41-43. URL: https://kns.cnki.net/kcms/detail/detail.aspx?dbcode=CJFD\&dbname $=$ CJFDAUTO\&filename $=$ WHCC202132017\&uniplatform $=$ NZKP T\&v=yiHNM8m6g323fOnT3YYzCMTn7d4UJt2B6onmAs_fuX WqBO3gx1JFCGntWJ01HQgL [in Chinese]

13. Huang, Weiwei. (2021). Application of Chinese Traditional Decorative Elements in Modem Interior Design Art. House, (30), 20-21. URL: https://kns.cnki.net/kcms/detail/detail.aspx?dbcode=CJFD\&dbname=CJF DAUTO\&filename $=J U S H 202130010 \&$ uniplatform $=N Z K P T \& v=p v 1 R$ 4giwQg_Cz0vlqUiMMIG7j3781_GcKY1GPGiMzyjkNClk-

Zt2ahH4aSoZXs_h [in Chinese]

14. Xie, Fei. (2021). Research and Application of Interior Decoration Design Based on Chinese Traditional Culture. Architecture and Culture, (10), 56-57. URL: https://kns.cnki.net/kcms/detail/detail.aspx?dbcode $=$ CJFD\&db name $=$ CJFDAUTO\& filename $=$ JZYW202110020\&uniplatfor $\mathrm{m}=\mathrm{NZKPT \& v=qSZIZKyJ9zkp0zd \_ o7Fr \_ xeFLbm9XNmTXm}$ o0OQLO-93tiWSj87wCBNDkA1FC6QVa [in Chinese]

15. Wang, Zhihong. (2021). Interior decoration design from the perspective of regional culture. Architecture, 51(19), 150-151. URL: https://kns.cnki.net/kcms/detail/detail.aspx?dbcode=CJFD\&dbname $=$ CJFDAUTO\&filename $=$ JCJG202119044\&uniplatform=NZKPT $\& \mathrm{v}=\mathrm{Xmv} 3 \mathrm{MT} 2 \mathrm{rnnlUgTWip3DRruumSMWNK7Aho83dHdKAi0}$ xJVqrb8VPhEI92FfXnx4J4 [in Chinese]

Рецензент: професор кафедри мистецтва Інь Гоуей, Університет Хучжоу, Китай.
Автор: КАЛІНІНА Марина Юріївна студентка
Університет Хучжоу
E-mail-254771778@gq.com 


\section{ОГЛЯД АРХІТЕКТУРИ ТА ДИЗАЙНУ ІНТЕР'ЄРІВ В КИТАЇ ТА ЄВРОПІ}

М.Ю. Калініна

Університет Хучжоу, Китай

Китайська та європейська культури розвивалися незалежно одна від іншої протягом сотень років. Від найпростіших повсякденних речей до мови, способу життя та мислення - абсолютно все це має радикальні відмінності. Наші погляди на життя, менталітет, уявлення про смерть, навіть методи виховання дітей $i$ віра відрізняються. Кожна з иих культур унікальна і неповторна. Усі иі відмінності в намому менталітеті відображаються не лише в способі життя та мисленні людей, а й у творчості. Адже творчість - ие відображення нашого існування. Музика, образотворче мистеитво, архітектура, дизайн, усі иі творчі напрямки несуть на собі відбиток намого життя, слід намих бажань $і$ вимог. У статті автор провела паралелі між такими різними і величними культурами, як китайська та європейська, простежила розвиток дизайну та архітектури, вплив иих двох традищій одної на іншу. Структура статті побудована на системному огляді питань стародавньої китайської традиції в архітектурі, сучасних будинків Китаю, специфіки архітектури китайських мегаполісів, традицій та сучасних тенденцій у розвитку свропейської архітектури. Серед останніх автором визначені: тенденція до екологізаиії навколишнього середовища (в контексті даного дослідження розглянуто екологічний дизайн та архітектура); все більше виражена схильність до персоніфікаиії, тобто індивідуальності в інтер 'єрі; функціональність, згідно якій в інтер 'єрі все частіше передбачається наявність лише корисних речей, тобто нічого зайвого; $і$ культурний обмін, тобто розглянуто, яким чином європейська культура вплинула на китайську, а також, які можливості відкриває Китай перед європейськими дизайнерами та архітекторами. 3'ясовано вплив глобалізаиії на появу нових синтетичних стилів як в Китаї, так і в європейських краӥнах.

Ключові слова: китайський, європейський, відмінності, мистецтво, традииї̈, модерн, будівництво, стиль, розвиток. 